\title{
Measurements of Insulin Activities in Pancreas and Serum of Mice with Spontaneous ("Obese" and "New Zealand Obese") and Induced (Goldthioglucose) Obesity and Hyperglycemia, with Considerations on the Pathogenesis of the Spontaneous Syndrome*
}

\author{
Werner Stiauffacher, André E. Lambert, Danièze Vecchto and Albert E. Renold
}

Institut de Biochimie Clinique, University of Geneva, Geneva, Switzerland

Summary. 1. Insulin-like activity (ILA) and immunoreactive insulin (IRI) of pancreatic extracts and of serum have been measured in lean and obese (obob) mice from the Jackson Memorial Laboratory in Bar Harbor, Maine; in New Zealand obese mice; and in goldthioglucose-obese Swiss mice, and their lean controls. In all three types of mice the relative amounts of "suppressible" and "nonsuppressible" insulin activities of serum have also been established. - 2. Pancreatic content of IRI in (obob) mice is much greater than in their lean sibblings at five months of age, but smaller at 5 weeks, whereas serum IRI and ILA of (obob) mice are greatly in excess of the same activities of serum from their lean littermates at both ages. It is suggested that increased peripheral demand for insulin preceeds increased insulin synthesis and storage in this type of obesity. - 3. In all three strains of mice, obese or lean, the ratio of biologic to immunologic activity of pancreatic extracts was constant and close to unity. In serum, this ratio was also constant but approximately five times greater than unity. These findings do not support the notion that differences in insulin structure might account for differences in the biological activity of insulin in obese and non-obese animals; they are in keeping with the concept of a potentiation of serum insulin activity by some component of serum in all mice. - 4. Approximately $90 \%$ of serum ILA in all three types of obese mice studied was suppressed in the presence of anti-insulin serum, although the absolute levels of non-suppressible ILA were similar to those reported for other species. It is unlikely, therefore, that "bound" insulin accounts for a significant part of the increased ILA of serum of any of the three types of obese animals studied. - 5. Present data support the concept of a marked tissue-bound muscular resistance to insulin action as an important, possibly primary pathogenetic feature in (obob) mice. A similar, but much less marked muscular resistance can be demonstrated in $\mathrm{NZO}$ mice, whereas muscular resistance to insulin action is totally absent in goldthioglucose obese Swiss mice after a 24 hour fast.

Mesure des activités insuliniques du pancréas et du sérum de souris présentant une obésité et une hyperglycémie spontanées ("obèse" et "obèse de Nowvelle Zélande") et induite (aurothioglucose) avec considérations sur la pathogénèse des syndromes spontanés.

Résumé. 1. L'activité insulinique (ILA) et l'insuline immunoréactive (IRI) ont été dosées dans des extraits pancréatiques et dans le sérum de souris maigres et obèses (obob) provenant du Jackson Memorial Laboratory à Bar Harbor, Maine; de souris obèses de Nouvelle Zélande; et de souris albinos rendues obèses par l'aurothioglucose. Chez ces trois types de souris, les quantités relatives

* This work was supported by the Fonds National Suisse de la Recherche Scientifique (Grant No. 3618), Berne,' Switzerland, the Fondation Emil Barell pour le développement de la recherche médico-scientifique, Basel, Switzerland, and the Diabetes Foundation, Inc., Boston, Massachusetts. Dr. LAMBeRT is aspirant of the Fonds National Belge de la Recherche Scientifique. d'activité insulinique "supprimable" et "non supprimable" ont également été mesurées dans le sérum. 2. Le contenu insulinique en IRI du pancréas des souris obob était beaucoup plus élevé que celui de leur fratrie maigre à l'âge de cinq mois, mais était moindre à l'âge de cinq semaines. Par contre, l'TRI et I'ILA du sérum des souris obob excédaient de beaucoup ceux de leur fratrie maigre aux deux âges. Il est suggéré que la demande périphérique augmentée en insuline précède la synthèse et le stockage insuliniques augmentés dans ce type d'obésité. - 3. Chez ces trois souches de souris, qu'elles soient obèses ou maigres, le rapport des activités insuliniques biologiques et immunologiques des extraits pancréatiques était constant et approchait l'unité. Dans le sérum, ce rapport était également constant mais il était approximativement de cinq. Ces faits sont en dósaccord avec la notion que des différences de structure de l'insuline pourraient être la cause des activités biologiques insuliniques différentes chez les animaux obèses et non obèses. Ils sont cependant en accord avec le concept d'une potentialisation de l'activité insulinique du sérum par une substance sérique présente chez toutes les souris. 4. Approximativement $90 \%$ de l'ILA sérique chez les trois races de souris obèses étudiées étaient supprimées par la présence de sérum anti-insuline, bien que les taux absolus d'ILA non supprimable soient semblables à ceux trouvés dans d'autres espèces. Il est donc improbable que l'insuline "liée" participe pour une part importante à 1'ILA sérique accrue d'un des trois types d'animaux obèses étudiés. -5 . Les résultats obtenus sont en accord avec lo concept d'une résistance importante du tissu musculaire à l'action insulinique qui jouerait un rôle pathogénique important, voire primordial, chez la souris obob. Une résistance musculaire similaire, bien que moins marquée, peut être démontrée chez la souris obèse de Nouvelle Zélande. Par contre, cette résistance musculaire à l'action insulinique est totalement absente chez la souris albinos rendue obèse par l'aurothioglucose, après un jeûne de 24 heures.

Biologische und immunologische Bestimmung des Insulins in Pancreas und Serum von Mäusen mit spon. taner ("obese" und "New Zealand obese") und induzierter (Goldthioglucose) Fettsucht und Hyperglylämie. Betrachtungen zur Pathogenese des spontan auftretenden Syndroms.

Zusammenfassung. 1. Pankreas-Extrakte und Seren von normalen und fettsüchtigen ("obob") Mäusen der Jackson Memorial Laboratories, Bar Harbor, von neuseeländischen fettsüchtigen Mäusen ("NZO") und von weißen Mäusen, die nach Injektion von Goldthioglucose fettsüchtig goworden waren, wurden auf ihren Gehalt an insulinähnlicher Aktivität ("ILA") und immunoreaktivem Insulin ("IRI") untersucht. In den Seren aller drei Stämme wurde der Anteil der gesamt-ILA bestimmt, der mit Antikörpern gegen Insulin nicht unterdrückt werden kann. - 2. Pankreas erwachsener "obob" enthält mehr, dasjenige junger enthält weniger IRI als Pankreas normalgewichtiger Tiere aus dem gleichen Wurf, wogegen Serum der "obob" unabhängig vom Alter der Tiere mehr IRI und ILA enthält als das der normalgewichtigen. Fs ist anzunehmen, daß bei dieser Form gene- 
tischer Fettsucht die Zunahme des peripheren Insulinbedarfs vor der Steigerung der Insulinsynthese und -Speicherung auftritt. - 3. Bei allen drei Mäusestämmen, ob fettsüchtig oder nicht, war das Verhältnis von ILA zu IRI der Pankreasextrakte konstant und betrug ca. 1. Im Serum war das Verhältnis ebenfalls konstant, betrug aber ca. 5. Damit erscheint es unwahrscheinlich, daßß strukturelle Unterschiede der Insulinmoleküle einzelner Mäusestämme für Aktivitätsunterschiede des Hormons zwischen normalen und fettsüchtigen Mäusen verantwortlich zu machen sind. Dagegen ist das Resultat im Einklang mit der Möglichkeit oiner Potenzierung der Aktivität des Insulins durch gewisse Serumproteine. 4. In Gegenwart von Antikörpern gegen Insulin wurden ca. 90\% der ILA des Serums aller drei untersuchten Mäusestämme unterdrückt. Die absolute Konzentration nicht unterdrückbarer ILA entsprach derjenigen, die bei anderen Species beschrieben wurde. Es ist deshalb nicht wahrscheinlich, daß ein "gebundenes" Insulin für die Erhöhung der Konzentration der ILA im Serum der untersuchten fettsüchtigen Mäuse verantwortlich ist. 5. Die vorliegenden Resultate unterstützen die Annahme, daß eine gewebeeigene Insulinresistenz der Muskulatur in der Pathogenese des "obob" Syndroms eine bedeutende Rolle spielt. Eine ähnliche, nicht notwendigerweise gewebegebundene und schwächere Insulinresistenz der Muskulatur ließ sich auch bei "NZO" Mäusen nachweisen, während die Muskulatur der durch Goldthioglucose hyperphagisch und fettsüchtig gemachten weißen Mäuse normal insulinempfindlich blieb.

Key-words: Spontaneous Diabetes, Genotype: C57BL/ 6J-ob, Mutation: obese, New Zealand obese (NZO), Goldthioglucose, Obesity: pathogenesis, Adipose tissue, Muscle, Resistance to insulin, Insulin in serum, Insulin in pancreas, Non-suppresible ILA, ILA.
Reports from this laboratory have suggested that a differential responsiveness of muscle and adipose tissue to the action of insulin might be involved in the pathogenesis of the obese hyperglycemic syndrome encountered in certain strains of genetically obese mice $[22,23]$. Since "bound" insulin has been reported to affect glucose metabolism of muscle less than that of adipose tissue, and was thus considered to be involved in the production of diabetes associated with obesity in man [1], we have considered the question of the existence and possible pathogenetic importance of such a modified form of insulin in genetically obese and hyperglycemic mice.

Obese mice ("obob") from the Jackson Memorial Laboratory colony in Bar Harbor [11] and New Zealand obese mice ("NZO") [2] are known to exihibit increased levels of insulin-like activity (ILA) in serum $[3,21]$ and pancreas $[21,25]$, as measured by bioassay procedures. Elevated concentrations of immunoreactive insulin (IRI) have been reported in the serum of obese rats with surgical hypothalamic lesions [8]. Direct comparison of results obtained in these studies is difficult because the experiments were performed at different times and under different conditions, with at least three different assay procedures.

In the present study, an attempt is made to compare serum insulin activity and pancreatic insulin content of two types of genetically obese mice with those of normal mice and of mice made obese by the injection of goldthioglucose. In addition, the simultaneous use of bioassay and immunoassay procedures on the same sample allowed for a tentative assessement of "bound" insulin, since this activity has been reported neither to be suppressed in the presence of anti-insulin serum, nor to react with it, and cannot therefore be measured in the immunoassay procedure [1].

\section{Materials and Methods}

Animals. New Zealand obese mice, derived from the original stock [2], arose from the inbred colony maintained in this laboratory. Bar Harbor obese mice (obob) and their lean littermates were purchased from the Jackson Memorial Laboratories, Bar Harbor, Maine, U.S.A. Swiss albino mice were obtained from S. Ivanovas, Kisslegg im Allgäu, Germany at the age of three weeks. They were kept in the laboratory for two weeks before they were injected with goldthioglucose $0.4 \mathrm{mg} / \mathrm{g}$ body wt. in $0.9 \%$ saline, intraperitoneally). Obese mice were used for experiments 4 weeks after the injection, i.e. at the age of 9 weeks. Non-injected animals of the same shipment served as "lean Swiss" control mice. All animals were fed a commercially available mouse chow (Altromin R, Kunath, Aarau, Switzerland) supplemented with a mixture of oats and seeds. "Fed" animals had free access to food and water until the time of sacrifice, while food was removed $24 \mathrm{~h}$ beforehand in "fasted" mice.

Samples. 6 animals of any given type were killed at the same time. They were decapitated with scissors without anesthesia and the blood of all 6 animals was pooled, left at room temperature for 2 hours, then centrifuged at $1500 \times G$ for 20 minutes. The serum was divided into two samples for bioassay and immunoassay, respectively, and stored at $-20^{\circ} \mathrm{C}$ until the time of assay. Immediately after bleeding, the pancreas was carefully excised and homogenized in ice-cooled acid ethanol [19]. After storage overnight at $4^{\circ} \mathrm{C}$ the samples were centrifuged at $4^{\circ} \mathrm{C}$ and 1000 $\times G$ for 20 minutes. The sediment was rehomogenized with acid ethanol and recentrifuged after further extraction at $4^{\circ} \mathrm{C}$ for $2 \mathrm{hr}$. The supernatant of the two extractions was pooled, well mixed, divided into two samples for immunoassay and bioassay and stored at $-20^{\circ} \mathrm{C}$ until the time of assay. Each pancreas was extracted individually and assays were performed on individual extracts.

Assay procedures. Radioimmunoassays were carried out according to method $\mathrm{C}$ of HALES and RaNDLE [9] with reagents purchased from the Radiochemical Centre, Amersham, England (Code IM 39). The method was modified as follows: the separation of bound and 
free insulin was performed according to MoRGAN and LAZAROW [12], and the incubation volumes of insulinbinding reagent, labelled insulin and of standard or unknown sample were doubled [27]. No mouse insulin was available as a standard. Therefore pork insulin, 10 times recrystallized (Novo, Copenhagen) was used. It was observed that the standard curve obtained with this insulin is similar to that obtained with serial dilutions of mouse pancreatic extracts [27].

Bioassays were carried out on rat epididymal adipose tissue using the routine procedure of this laboratory [17, 20]. Assays with an index of precision $(\lambda)$ exceeding 0.25 were discarded. In bioassays carried out in the presence of guinea pig anti-insulin serum it was ascertained that enough antibody was present to suppress the activity of an amout of crystalline insulin corresponding to or exceeding that of the ILA contained in the serum sample.

\section{Results}

IRI in pancreas and serum. The main characteristics of the different types of mice used and the corresponding values for pancreatic and serum IRI are indicated in Table 1. In each age group, obese animals of a given observed in pancreas of 5 week old mice of the Bar Harbor strain were lower than those of their lean litter-mates or those found in other animals with the exception of 18 days old NZO mice. This finding was confirmed by histological examination: Aldehydethionine stained sections of pancreas of the 5 week old Bar Harbor obese mice were poorly granulated, whereas sections obtained from adult animals were rather better granulated than those of other obese or lean mice (unpublished observation.) Fasting for 24 hours had no significant effect on pancreatic insulin content of adult Bar Harbor obese mice; in young animals it could not be tested for technical reasons. In NZO mice, total pancreatic IRI content increases with age. However, with the exception of the 5 months old animals, the results did not significantly differ from those of lean Swiss or lean Bar Harbor mice. The results obtained in lean Swiss mice are comparable with those of lean Bar Harbor mice. In fed goldthioglucose-obese mice, total as well as relative pancreatic IRI content is not significantly higher than in the control mice of the same age. However, after fasting, the difference between the two groups becomes significant.

Table 1. IRI in serum and pancreas of lean and obese mice

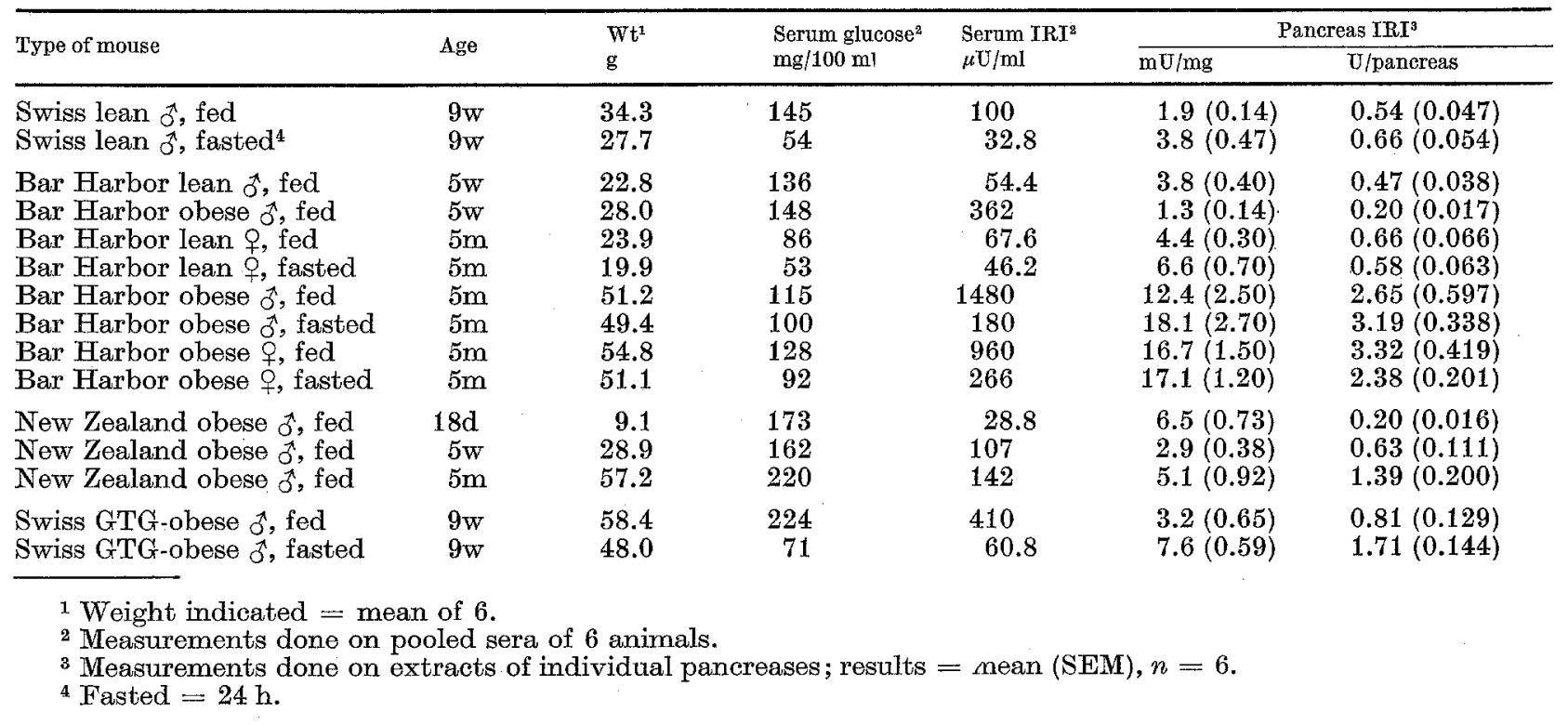

type are significantly heavier than the lean control animals. All adult obese mice are of comparable weight. Clearcut hyperglycemia was only observed in NZO and goldthioglucose obese Swiss mice, whereas Bar Harbor obese mice were only very moderately hyperglycemic.

In Bar Harbor obese mice pancreatic insulin content, both per unit wet weight and per whole pancreas, increases with age. In adult animals it exceeds that found in their lean litter-mates as well as that of any other type of mice examined. However, the values
The concentration of serum IRI of Bar Harbor obese mice is increased 5 to 20 fold above control values at all ages tested. Fasting for 24 hours reduces the hyperinsulinemia but the concentrations remain 5 to 6 times higher than those of lean litter-mates identically treated. Note that the serum concentration at 5 weeks is elevated, even though pancreatic IRI at that time is low. The concentration of IRI in serum of 18 days old NZO mice is similar to or lower than that measured in lean Swiss or lean Bar Harbor mice; with increasing age it increases to values slightly 
higher than those of lean mice. However, in 5 months old NZO mice variations of concentrations of IRI in serum were observed that were encountered with no other type of mice: in one pool of serum obtained from seemingly identical mice, in which only serum but not pancreatic IRI and ILA were measured, the concentration of IRI was $775 \mu \mathrm{U} / \mathrm{ml}$ and therefore comparable with that of Bar Harbor obese mice. In Swiss mice the induction of obesity with hyperphagia was accompanied by a significant rise of serum IRI concentrations to values 4 to 5 times greater than those observed in control mice. Fasting for 24 hours was followed by a fall in serum IRI to values comparable with those observed in lean animals.

Comparison between IRI and ILA in pancreas. Comparative values of IRI and ILA obtained on extracts of individual pancreas of the different types of mice used are shown in Table 2. Despite the inevi-

Table 2. Comparison of individual values for ILA and IRI in pancreases of lean and abese mice 1

\begin{tabular}{|c|c|c|c|c|c|}
\hline \multicolumn{2}{|c|}{ Lean Swiss } & ILA & IRI & \multicolumn{2}{|c|}{ New Zealand obese } \\
\hline ILAA & IRI & 7.8 & 6.9 & ILA & IRI \\
\hline 3.3 & 2.9 & $\overrightarrow{\mathrm{x}}=3.8$ & $\overline{\mathrm{x}}=4.6$ & 2.0 & 4.4 \\
\hline 3.8 & 3.1 & $\overline{(0.72)}$ & $(0.46)$ & 3.4 & 5.9 \\
\hline 5.0 & 4.8 & & & 3.6 & 3.4 \\
\hline $\overrightarrow{\mathrm{x}}=4.0$ & $\overline{\mathrm{x}}=3.6$ & Obese $\mathrm{Ba}$ & r Harbor & 3.8 & 5.1 \\
\hline & & 0.5 & 1.0 & 4.0 & 3.2 \\
\hline GTG-ob & se Swiss & 1.4 & 1.1 & 4.3 & 2.3 \\
\hline 5.8 & 6.2 & 10.4 & 10.6 & 4.3 & 3.0 \\
\hline 7.8 & 8.6 & 12.6 & 14.6 & 5.2 & 1.6 \\
\hline 9.4 & 7.1 & 18.6 & 14.0 & 5.5 & 5.9 \\
\hline$\overline{\mathrm{x}}=7.3$ & $\overline{\mathrm{x}}=7.0$ & 19.1 & 12.5 & 6.7 & 6.6 \\
\hline & & 19.5 & 19.4 & 6.8 & 6.1 \\
\hline Lean Ba & Harbor & 21.0 & 15.2 & 7.0 & 6.2 \\
\hline 1.6 & 4.3 & 27.0 & 17.8 & 7.5 & 10.8 \\
\hline & 28 & 29.3 & 22.4 & 9.1 & 4.9 \\
\hline 1.8 & 3.0 & 29.8 & 20.8 & $\overline{\mathrm{x}}=5.2$ & $\bar{x}=4.95$ \\
\hline 2.7 & $\begin{array}{l}3.0 \\
50\end{array}$ & 31.3 & 21.7 & $\overline{(0.52)}$ & $\overline{(0.6)}$ \\
\hline 0.4 & 5.0 & 36.0 & 28.4 & & \\
\hline 4.8 & 3.8 & $\overrightarrow{\mathrm{x}}=9.18$ & $\bar{x}=15.3$ & & \\
\hline 5.0 & 5.7 & $\overline{(3.1)}$ & $\overline{(2.2)}$ & & \\
\hline
\end{tabular}

${ }^{1}$ All values in $\mathrm{mU} / \mathrm{mg}$ wet wt pancreas. ILA and IRI were measured on aliquots of the same extraction sample in each instance. $\bar{x}=$ mean (S.E.M.). Values are listed ir respective of age, sex or feeding state.

table variability due primarily to the lesser precision of the bioassay procedure, the results obtained with the two assays are in good agreement. This is expressed in the close checks between the mean values of each group of assays and, more precisely, in the coefficients of correlation, which were significant to less than 0.01 in each group. In pancreas containing normal amounts of insulin, values for IRI are frequently somewhat higher than those obtained by bioassay, while the reverse is true for pancreas with high insulin content per unit wet weight. Regression lines calculated from the results shown in Table 2 are shown in Fig. 1. The results for Swiss mice are not indicated because of the limited number of observations. The slopes of the three lines are similar and do not differ significantly from the ideal line $y=x$.
Bioassays in the presence of anti-insulin serum were performed on several pancreas extracts of each type of mouse. In all instances pancreatic ILA was found to be completely suppressed by insulin antisera (data not shown).

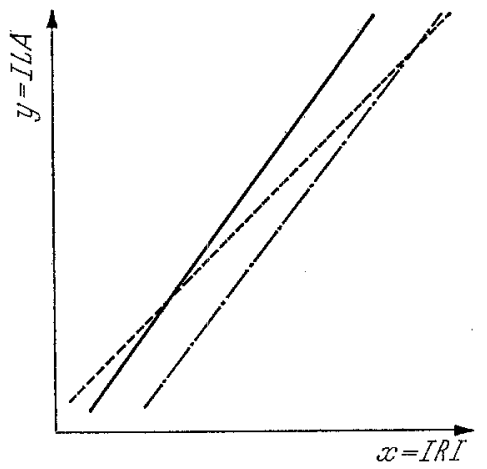

Fig. 1. Quantitative relationship between IIAA (y) and IRI $(\mathrm{x})$ of pancreas of obese mice.

-..-..- Lean Bar Harbor: $\quad y=1.25 \mathrm{x}-2$

$\mathrm{r}=0,79 \mathrm{p}<0,01(\mathrm{n}=8$ pairs of values $)$ $y=1,32 x-0.4$

$r=0.96 p<0.01(n=13$ pairs of values $)$

$-\rightarrow+=$ New Zealand obese: $r=0.49 \mathrm{p}<0.01(\mathrm{n}=14$ pairs of values $)$.

Table 3. Qantitative relationship between ILA and IRI in serum of obese mice

\begin{tabular}{lrccl}
\hline Type of mouse & \multicolumn{1}{c}{ ILA } & IRI & Ratio & Mean Ratios \\
& $\mu \mathrm{U} / \mathrm{ml}$ & \multicolumn{1}{c}{$\begin{array}{l}\mu \mathrm{U} / \mathrm{ml} \\
\text { ILA/IRI }\end{array}$} & \\
\hline Swiss lean & 168 & 32.8 & 5.1 & \\
& 360 & 100 & 3.6 & \\
Bar Harbor lean & 950 & 52.0 & 8.7 & 5.8 \\
& 210 & 46.2 & 1.9 & \\
& 510 & 67.6 & 3.1 & \\
Bar Harbor obese & 660 & 180 & 3.7 & \\
& 750 & 266 & 2.8 & \\
& 2200 & 960 & 2.3 & \\
& 4600 & 362 & 12.7 & \\
& 8500 & 1480 & 5.7 & 5.4 \\
New Zealand obese & 100 & 28.8 & 3.5 & \\
& 370 & 142 & 2.6 & \\
& 720 & 107 & 6.7 & \\
& 6600 & 775 & 8.5 & 5.3 \\
Swiss GTG-obese & 350 & 60.8 & 5.8 & \\
& 2700 & 410 & 6.6 & \\
& 3870 & 547 & 7.1 & 6.5
\end{tabular}

1 ILA and IRI were measured on aliquots of the same serum pool in each instance. Values are listed irrespective of age, sex and feeding state.

Comparison between IRI and ILA in serum. Results of experiments where IRI and ILA were determined on samples of the same serum pools are shown in Table 3 together with the individual and mean ratios of ILA/IRI. In contrast to the results obtained with pancreatic extracts, the concentration of serum ILA is consistently higher than that of IRI. Although there is considerable variation with respect to the ratios ILA/IRI of individual serum pools, the mean values for the $\mathbf{5}$ groups of lean and obese mice are strikingly 
similar. Therefore, all values were plotted on the same graph and the comprehensive regression line for all results was calculated (Fig. 2). The slope of the result-

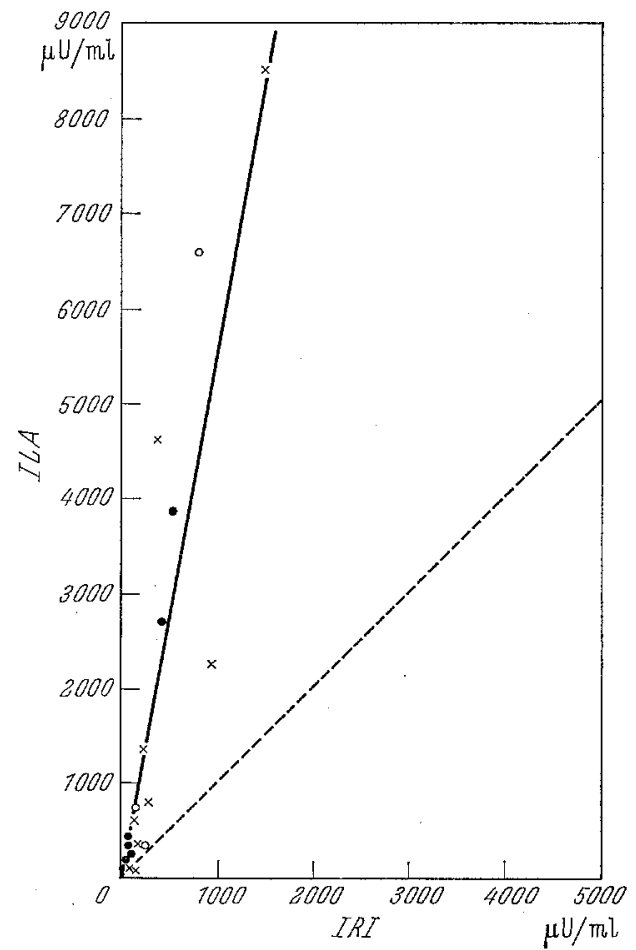

Fig. 2. Correlation between ILA (y) and IRI $x$ ) of serum of different types $\mathrm{y}=5.5 \mathrm{x}+109 ; \mathrm{r}=0.87 \mathrm{p}<0.01$

$\mathrm{x}=8$ Bar Harbor (lean and obese)

$\mathrm{O}=4$ New Zealand obese (NZO)

$=6$ Swiss mice (lean and GTG obese)

.$-=$ line of identity, $x=y$ of each type of animal were therefore assayed in the presence of anti-insulin serum. Due to the small amounts of serum available per pool, most of the bioassays with anti-insulin serum had to be carried out at relatively high dilutions. In these cases, all serum ILA turned out to be "suppressible" by antibodies, and only maximum values could be calculated for the concentration of "non-suppressible" ILA, according to the dilutions used. In three instances, however, it was possible to analyze pools at convenient dilutions, so as to obtain true values for "non-suppressible" ILA. These results are shown in Table 4 together with the concentrations of ILA and IRI of the same sera. It is evident that "non-suppressible" ILA can in no case account for the difference between ILA and IRI. The relative contribution of "non-suppressible" ILA to total ILA is similar in all three types of obese mice examined and accounts for about $10 \%$ of total ILA.

\section{Discussion}

In the studies reported on here we have attempted to obtain comparable values of both ILA and IRI in serum and pancreas of three types of experimental obesity in mice, two of them genetic in origin. Our results confirm and extend the bioassay findings of WRENSHALl et al. [25] and CHRISTOPHE et al., [3] in that pancreatic extracts and sera of Bar Harbor obese mice were found to contain significantly more immunoreactive as well as biologically active insulin than those obtained from lean littermates. In the case of serum, it is to be emphasized that the elevation was a very striking one, with IRI levels in serum from fed animals ranging from 5 to 20 times those observed in either lean Bar

Table 4. Suppression of ILA of serum of obese mice by anti-insulin serum

\begin{tabular}{|c|c|c|c|c|c|c|}
\hline \multirow{2}{*}{$\begin{array}{l}\text { Type of mouse } \\
\text { (pools of } 6 \text { ) }\end{array}$} & \multirow{2}{*}{$\begin{array}{l}\text { Serum IRI } \\
\mu \mathrm{U} / \mathrm{ml}\end{array}$} & \multirow{2}{*}{$\begin{array}{l}\text { Serum } \amalg A \\
\mu \mathrm{U} / \mathrm{ml}\end{array}$} & \multirow[t]{2}{*}{ Dilution used } & \multicolumn{2}{|c|}{ Not suppressible $\amalg A$} & \multirow{2}{*}{$\begin{array}{l}\text { Index of pre- } \\
\text { eision of assay }\end{array}$} \\
\hline & & & & $\overline{\mu \mathrm{U} / \mathrm{ml}}$ & $\%$ of total ILA & \\
\hline $\begin{array}{l}\text { Obese Bar Harbor }(5 \mathrm{~m}) \\
\left.\text { (Pool } \sigma^{\star}+\text { o } 1: 1\right)\end{array}$ & 1220 & 5350 & $1: 6$ & 360 & 6.7 & 0.18 \\
\hline New Zealand obese $(5 \mathrm{~m})$ & 775 & 6600 & $1: 12$ & 480 & 7.3 & 0.16 \\
\hline Swiss GTG-obese (9 w) & 574 & 3875 & $1: 8$ & 320 & 8.4 & 0.09 \\
\hline
\end{tabular}

ing line is strikingly different from that of the lines obtained with pancreatic extracts and from the ideal line $y=x$. It is practically identical with the line that was also calculated from the results obtained with lean and obese Bar Harbor mice alone (not shown), thereby suggesting that there is no striking difference between the serum insulins of these three types of mice with respect to their behavior in presence of insulin antiserum or their activity on rat adipose tissue.

Because of the difference between pancreatic extracts and serum with respect to the quantitative relationship between ILA and IRI, attempts were made to determine whether the "excessive" ILA of serum represented "non-suppressible" ILA [5, 18] and thus possibly "bound" insulin [1]. A number of sera
Harbor litter-mates or Swiss albino controls, while the corresponding differential for serum from fasting animals was 4 to 5 fold. Furthermore, this elevation could in no way be accounted for as a response to elevated blood glucose levels, since the differences in blood glucose were small and since the elevation was just as striking when corrected to a standard concentration of blood glucose.

While both serum IRI and pancreatic IRI of Bar Harbor obese mice increased with age, it is of interest to note that in the 5 week old obese animals serum IRI was significantly elevated in comparison with lean littermates, while pancreatic IRI, both per total pancreas and per unit wet weight of pancreas, was lower than that of the lean littermates. This finding 
suggests that an increased peripheral demand for insulin existed in the 5 week old mice, and that it was met by pancreatic insulin secretion, insulin biosynthesis, however, not being sufficient to allow for normal storage. With increasing age, the peripheral demand for insulin, as expressed by the high serum IRI relative to glucose concentration, persisted. However, insulin synthesis now appeared to have adapted, in that large amounts of insulin were stored in the pancreas as well. This apparent capability for progressive adaptation to an increased peripheral demand is in striking contrast to the relatively rapid pancreatic exhaustion, in presence of increased peripheral demands, that has been observed in other types of mice where an initial period of obesity, coexistant with moderate degrees of hyperglycemia and hyperinsulinemia, is followed by the development of true insulin deficiency $[6,10]$; or in the sand rat [7] where a similar process of pancreatic exhaustion has been induced by a sudden increase in caloric intake. True pancreatic exhaustion and the development of frank ketotic diabetes has not been described in Bar Harbor obese mice, although the serum levels of ILA have been found to fall with age [3].

The results obtained with NZO mice agree well with the values reported by SNEYD [21], although we have explored a much narrower age range. Both pancreatic and serum IRI increased with age. In serum, considerable variation was observed with respect to IRI and ILA. Although values only slightly higher than normal were observed in some samples, IRI and ILA concentrations in others were comparable with those of Bar Harbor obese mice. An assessment of the significance of this variability is not possible at this time, but it is in agreement with the marked heterogeneity in an apparently homogeneous population of NZO mice with respect to glucose tolerance, as described by CRofford and Davis [4]. normal, but returned to normal after $24 \mathrm{hr}$ of fasting. The increase in pancreatic insulin content after fasting may well be the expression of a temporary persistence of enhanced insulin synthesis in the presence of diminished release.

In relation to serum glucose concentration, all Bar Harbor obese mice, some NZO mice, and the fed goldthioglucose-obese Swiss mice displayed striking relative hyperinsulinemia, and thus evidence for insulin resistance. Fasting abolished this resistance in the exogenous obesity of the goldthioglucosetreated Swiss mice, while that of Bar Harbor obese mice was decreased but not abolished. Overall insulin resistance, as encountered in obese man as well as in various forms of experimental obesity, has often been attributed to a preferential insulin resistance of muscular tissue, while adipose tissue was thought to remain sensitive to the hormone. Such a differential sensitivity to the action of insulin could account for the coexistence of obesity, hyperglycemia and hyperinsulinemia. While direct proof of such a pathogenetic mechanism is still lacking with respect to the human syndrome, experiments using a modification of the intraperitoneal assay of insulin effectiveness on diaphragm muscle and epididymal adipose tissue $[14,15]$ have been performed on Bar Harbor obese, NZO and goldthioglucose obese Swiss mice, and are in accord with the existence of such a mechanism in the two genetic obese hyperglycemic syndromes tested [22, 23]. In these experiments, the ratio "diaphragm/adipose tissue" ("D/AT") was chosen to express the activity of glucose incorporation into diaphragm muscle glycogen, relative to that into adipose tissue lipids, both in the absence and in the presence of graded amounts of insulin. As seen from the data shown in Table 5, D/AT ratios remained extremely low at all concentrations of insulin tested in Bar Harbor obese mice, while $\mathrm{D} / \mathrm{AT}$ ratios in goldthioglucose obese

Table 5. Diaphragm/adipose tissue ratios of lean and obese mice

\begin{tabular}{llllll}
\hline \multirow{2}{*}{ Type of mouse } & \multicolumn{4}{c}{ Insulin $(\mu \mathrm{U} / \mathrm{ml}$ injection fluid } \\
\cline { 2 - 6 } Lean Swiss & $0.14 \pm 0.07$ & $1.10 \pm 0.34$ & $1.10 \pm 0.22$ & $1.01 \pm 0.17$ & 30000 \\
& $(6)$ & $(5)$ & $(6)$ & $(6)$ & \\
Bar Harbor & $0.01 \pm 0.003$ & $0.01 \pm 0.001$ & $0.04 \pm 0.01$ & $0.06 \pm 0.03$ & $0.08 \pm 0.02$ \\
obese & $(6)$ & $(6)$ & $(5)$ & $(4)$ & $(5)$ \\
New Zealand & $0.03 \pm 0.01$ & $0.03 \pm 0.01$ & $0.34 \pm 0.07$ & $1.47 \pm 0.25$ & \\
obese & $(5)$ & $(5)$ & $(5)$ & $(6)$ & \\
Swiss GTG-obese & $0.08 \pm 0.04$ & $0.98 \pm 0.27$ & $1.60 \pm 0.14$ & $2.00 \pm 0.2$ & \\
& $(4)$ & $(5)$ & $(6)$ & $(7)$ &
\end{tabular}

All values: mean \pm S.E.M. ()$=$ number of animals. All animals 8 weeks old, fasted 24 hours. From [22].

In fed, goldthioglucose-obese Swiss mice, pancreatic insulin content was found to be comparable with that of fed control animals. In fasted animals, it was significantly greater than that of the controls. Serum IRI of the fed animals was considerably increased above
Swiss mice demonstrated a brisk response to insulin of both diaphragm and adipose tissue, and were indistinguishable from $\mathrm{D} / \mathrm{AT}$ ratios seen in lean Swiss mice. Since these experiments were performed with fasted $(24 \mathrm{hr}$ ) animals, the absence of resistance to 
insulin in muscle of goldthioglucose obese mice is in agreement with the serum concentrations of IRI or ILA and glucose in the fasted goldthioglucose-obese mice (Table 1). The $\mathrm{D} / \mathrm{AT}$ ratios obtained in $\mathrm{NZO}$ mice suggest the existence of an insulin resistance of muscular tissue which is less marked than in Bar Harbor obese animals and which is overcome by increasing concentrations of insulin in the injection fluid.

These findings clearly establish the existence of a relative resistance to insulin of muscle over adipose tissue in the two genetic types of obesity examined here, when compared with the relative sensitivities of the two tissues in normal mice. Such a relative resistance to the action of insulin on muscle over adipose tissue, resulting in overall insulin resistance, could be the consequence of several mechanisms, of which we shall mention four: the presence of a "bound" form of insulin, necessitating the "release" of free insulin for effeativeness on muscle [1]; the presence of one or more circulating antagonists or inhibitors of insulin action, with greater inhibitory activity upon muscular tissue $[16,24,26]$; differential potentiation of insulin activity by serum protein resulting in greater activity of insulin upon adipose tissue [13]; or finally an intrinsic resistance to insulin of muscular tissue itself.

The results reported here do not favour the possibility that "bound" insulin contributes to the pathogenesis of the obese hyperglycemic syndrome examined, since the suppression of more than $90 \%$ of total ILA of serum from these animals in the presence of anti-insulin serum does not fit the characteristics described for "bound" insulin [1]. Furthermore, it is of interest to note that the ratio of immunologic to biologic activity of pancreatic insulin is close to unity and essentially identical for genetically obese, induced obese, or non-obese mice (Table 2, Fig. 1), thereby suggesting that there is little or no immunologic or biologic difference between the extracted pancreatic insulins of these animals.

In Bar Harbor obese mice, we have previously established that serum obtained from either obese or non-obese animals exerts no inhibitory effect upon the action of insulin on muscle after its intra-peritoneal injection into normal mice [22], suggesting that the primary importance of a circulating antagonist or inhibitor of insulin action is unlikely. Since the most striking feature of the experiments briefly summarized in Table 5 is that of an almost total absence of muscular response to intra-peritoneally injected insulin in this syndrome, we presently feel that the most likely contribution of insulin resistance to the pathogenesis of this obese hyperglycemic state is that of a marked primary resistance of muscle toward the action of the hormone. Of course, the nature of this primary muscular anomaly is as yet unknown. Since the degree of the resistance increases with age, it may be the result of the accumulation of a circulating inhibitor, or represent an intrinsic structural or metabolic anomaly.
The marked overall insulin resistance of goldthioglucose-obese Swiss mice in the fed state, its reversal by fasting, and the absence of muscular resistance to intraperitoneally injected insulin after a 24 hour fast, do not suggest the participation in this resistance to insulin of an antagonist of the synalbumin type [24], which is not known to be sensitive to the feeding schedule. It is, however, entirely consistent with the hypothesis [26] that feeding may give rise to the production of an insulin inhibitor capable of shifting caloric flux to storage rather than to immediate oxidative utilization, and that this antagonist is lacking in fasted animals.

Finally, it is noteworthy that antibody suppressible serum ILA exceeded the concentration of IRI by a factor of four or five fold in all mice tested in the present study, and that this factor was quite a constant one. This finding is consistent with the possibility that some serum component potentiates the activity of insulin secreted by both lean and obese mice, as has been reported for human serum [13]. However, since the degree of such an apparent and still hypothetical potentiation was similar, in the present studies, for lean and obese mice of all types used, a participation of this mechanism in the pathogenesis of any one of the three types of obesity under scrutiny, appears unlikely. The significance of this observation is as yet unknown.

Acknowledgements. The authors are indebted to Dr. E.B. Hershberg, Shering Corporation, Bloomfield, New Jersey, U.S.A. for generously supplying the goldthioglucose, and to Dr. J. SchuICHTKRULL, Novo Research Laboratories, Copenhagen, Denmark, for the specially purified standard of porcine insulin. The expert technical help of Miss Maya Herzog and Miss Josette LEUBA is gratefully acknowledged.

\section{References}

[1] Antoniades, H.N., J.A. Bougas, R. CameriniDavalos and H.M. PYKE: Insulin regulatory mechanisms and diabetes mellitus. Diabetes $\mathbf{1 3}$, $230-240$ (1964).

[2] Bielschowsky, M., and F. Bielschowsky: A new strain of mice with hereditary obesity. Proc. Univ. Otago med. Sch. 31, 29-31 (1953).

[3] Christophe, J., Y.M. Dagenais and J. Mayer: Increased circulating insulin-like activity in obese hyperglycemic mice. Nature (London) 184, 61-62 (1959).

[4] Crofford, O.B., and C.R. Davis: Growth characteristics, glucose tolerance and insulin sensitivity of New Zealand obese mice. Metabolism 14, 271-280 (1965).

[5] Fromsch, E.R., H. Burgi, E.B. Ramseier, P. Badiy and A. LABHART: Antibody-suppressible and nonsuppressible insulin-like activity in human serum and their physiologic significance. J. clin. Invest. 42, $1816-1834$ (1963).

[6] Gonet, A.E., W. Stadfhacher, R. Pictert and A.E. Rerold: Obesity and diabetes mellitus with striking congenital hyperplasia of the islets of Langerhans in spiny mice (Acomys Cahirinus). Diabeto$\operatorname{logia} 1,162-171(1965)$. 
[7] Hackel, D. B., L. FromaN, A. B. Mrkat, H. E. LeboVITZ, K. SCHMIDT-NIELSEN and T. Kinney: Effect of diet on the glucose tolerance, plasma insulin levels of the sand rat (Psammomys obesus). Diabetes 15, $105-114(1966)$.

[8] Hales, C.N., and G.C. Kennedy: Plasma glucose, non-esterified fatty acid and insulin concentrations in hypothalamic-hyperphagic rats. Biochem. J. 90, $620-624(1964)$.

[9] - and P.J. RANDLE: Immunoassay of insulin with insulin antibody precipitate. Biochem. J. 88, $127-146(1963)$.

[10] Hummes, K.P., M.M. Dickie and D.L. Colemar: Diabetes, a new mutation in the mouse. Science 153, $1127-1128(1966)$

[11] Ingalls, A.M., M.M. Dickie and G.D. SNeLL: Obese, new mutation in the house mouse. J. Hered. 41, $317(1950)$.

[12] Morgar, C.R., and A. LAzarow: Immunoassay of insulin: two antibody system. Plasma insulin levels of normal, subdiabetic and diabetic rats. Diabetes 12, $115-126(1963)$

[13] Power, L., C. Lucas and J.W. Conn: A globulin system from human serum that augments the activity of crystalline insulin on the epididymal fad pad; deficiency in diabetes mellitus. Metabolism 14, $104-109$ (1965).

[14] RaFaflsen, O.: Glycogen content of rat diaphragm after intraperitoneal injection of insulin and other hormones. Acta. physiol. scand. 61, 314-322 (1964).

[15] - V. LAURIS and A.E. ReNold: Localized intraperitoneal action of insulin on rat diaphragm and epididymal adipose tissue in vivo. Diabetes 14, $19-26$ (1965).

[16] REcan', L., and H. Atr: Insulin inhibitors and adipose tissue metabolism. Ann. N. Y. Acad. Sci. 131, $334-343$ (1965).

[17] Renold, A.E., D.B. Martin, Y.M. Dagenais, J. Steinke, R.J. Nickerson and M.C. ShePs: Measurement of small quantities of insulin-like activity using rat adipose tissue: I A proposed procedure. J. clin. Invest. 39, 1487-1498 (1960).
[18] Samaan, N., R. Fraser and W.J. Dempstier: The "typical" and "atypical" forms of serum insulin. Diabetes 12, 339-348 (1963).

[19] Sсотт, D.A., and A.M. Fismer: The insulin and zine content of normal and diabetic pancreas. J. clin. Invest. 17, 725-728 (1938).

[20] SHeps, M.C., R.J. NICKERson, Y.M. DageNats, J. Stemkke, D.B. Martin and A.E. Renold: Measurement of small quantities of insulin-like activity using rat adipose tissue: II Evaluation of performance. J. clin. Invest. 39, $1499-1510$ (1960).

[21] SNEYd, J.G.T.: Pancreatic and serum insulin in the New Zealand strain of obese mice. J. Endocr. 28, $163-172$ (1964).

[22] Stauffacher, W., B. Jeanrenaud and A.E. ReNOLD : Métabolisme du glucose dans le tissue adipeux et le muscle des animaux présentant une obésité métabolique ou une obésité par hyperphagie. Belg. clin. Acta. In press.

[23] - O.B. Chofford, B. Jeankenaud and A.E. RENOLD: Comparative studies of muscle and adipose tissue metabolism in lean and obese mice. Ann. N.Y. Acad. Sci. 131, 528-540 (1965).

[24] VALIANCE-OWEN, J.: Synalbumin antagonism. Diabetes 13, 241-246 (1964).

[25] WRENSHaIt, G.A., S.B. ANDRUS and J. MaYer: High levels of pancreatic insulin coexistent with hyperplasia and degranulation of beta cells in mice with the hereditary obese-hyperglycemic syndrome. Endocrinology 56, 335-340 (1955).

[26] Young, D.A.B., and B. Benson: Control of the serum insulin inhibitor by feeding. Diabetologia 2, 227 (1966)

[27] ZAHND, G.R., and A. LUYCKX: Personal communication.

Dr. WERner STAUFFACHER

Institut de Biochimie Clinique

Sentier de la Roseraie

CH-1211 Genève 4, Suisse 